\title{
Contamination of commercially available quisqualic acid by glutamate-like and aspartate-like substances
}

\author{
Jang-Ho J. Cha, Zane R. Hollingsworth, J. Timothy Greenamyre and Anne B. Young \\ Department of Neurology and Neuroscience Program, University of Michigan Medical School, Ann Arbor, MI 48104-1687 (U.S.A.)
}

(Received 21 April 1988)

(Revised 4 October 1988)

(Accepted 8 October 1988)

Key words: Quisqualate; High-pressure liquid chromatography; Glutamate; Aspartate, Contamination

\begin{abstract}
Six different batches of the glutamic acid analogue quisqualic acid were analyzed with high-pressure liquid chromatography (HPLC). All batches examined showed contaminant peaks. Different batches had different contaminant peaks and differing amounts of each contaminant. Every batch of quisqualic acid tested demonstrated a contaminant peak which co-eluted with exogenously added glutamic acid. Certain batches possessed a contaminant which co-eluted with aspartic acid. The levels of glutamate-like contamination ranged from 0.08 to $0.60 \%$, and the levels of aspartate-like contamination ranged from undetectable amounts to $0.80 \%$. The amount of combined glutamate- and aspartate-like contamination of each batch of quisqualate correlated very highly with the ability of that batch to interact with non-quisqualate receptors in an autoradiographic binding assay. These non-quisqualate receptors are likely $N$-methyl-D-aspartate (NMDA) receptors. Thus, when high concentrations of quisqualate are used experimentally. contamination is likely to produce spurious effects at non-quisqualate glutamate receptors. Quisqualate itself may be a more specific agonist than assumed previously.
\end{abstract}

\section{Introduction}

Quisqualic acid is an analogue of glutamic acid which preferentially interacts with the quisqualate subtype of glutamate receptors (Watkins and Evans, 1981). At relatively high concentrations, quisqualate interacts with $N$-methyl-D-aspartate (NMDA)-type glutamate receptors (Olverman et al., 1984; Greenamyre et al., 1985; Foster and Fagg, 1987; Cha et al., 1988). Quisqualate may interact with NMDA receptors as a non-selective agonist, or, alternatively, there may be contaminant amino acids present in quisqualate preparations, such that at high concentrations of quisqualate, the contaminants interact with NMDA receptors. Commercially available quisqualate is

Correspondence: A.B. Young, Neuroscience Laboratory Building, University of Michigan, 1103 East Huron, Ann Arbor, MI 48104-1687, U.S.A. either synthesized or purified from the berries of Quisqualis indica and $Q$. fructus via a process by which small quantities of naturally occurring glutamate and aspartate might remain in the final product. We report the presence of contaminants which behave identically to glutamate and aspartate in HPLC. We have also examined the correlation between the amount of contamination in different batches of quisqualate and the potency of those batches in displacing $\left[{ }^{3} \mathrm{H}\right]$ glutamate in an autoradiographic binding assay.

A preliminary report has been published (Cha et al., 1987).

\section{Materials and Methods}

\section{Materials}

Quisqualic acid was obtained from Sigma (St. Louis, MO), Research Biochemicals (Wayland, MA) and Cambridge Research Biochemicals (Val- 
ley Stream, NY). Additional synthetic quisqualic acid was a generous gift from Dr. J.F. Collins. L- $\left[{ }^{3} \mathrm{H}\right]$ Glutamic acid (specific activity 36 to 53 $\mathrm{Ci} / \mathrm{mmol}$ ) was obtained from Amersham (Arlington Heights, IL). All other compounds were purchased from Sigma. All solvents were of HPLC grade.

\section{High-pressure liquid chromatography (HPLC)}

HPLC analysis was performed using a reverse phase $\mathrm{C} 18$ column and gradient elution. The organic phase was methanol : acetonitrile: tetrahydrofuran $(5: 4: 1)$ and the aqueous phase was 50 $\mathrm{mM}$ sodium acetate, $\mathrm{pH}$ 5.0. For gradient elution, the initial percent organic phase was $32 \%$, with a flow rate of $0.5 \mathrm{ml} \mathrm{min"1.} \mathrm{At} t=9 \mathrm{~min}$, the percentage of organic phase was increased in a linear fashion while maintaining the same flow rate. When the percent organic phase reached $80 \%$ at $t=13 \mathrm{~min}$, the percent of organic phase was linearly reduced to $32 \%$ over the next $6 \mathrm{~min}$. Thereafter, the percent organic phase remained at $32 \%$. Amino acids were derivatized precolumn with $O$-phthaldialdehyde/ethanethiol (Fernstrom and Fernstrom, 1981), injected in a sample volume of $10 \mu \mathrm{L}$ and were detected fluorometrically, with an emission filter cut off of $470 \mathrm{~nm}$. Quantification of contaminants was carried out by adding increasing concentrations of either $\mathbf{L}$-aspartate or $\mathbf{L}$ glutamate to samples of quisqualate and performing linear regression analysis on the resultant peak heights.

\section{Receptor autoradiography}

A detailed description of the method for glutamate receptor autoradiography has been published (Greenamyre et al., 1984, 1985). Briefly, male Sprague-Dawley rats $(175-250 \mathrm{~g})$ were decapitated, and the brains quickly removed and frozen under powdered dry ice. Twenty $\mu \mathrm{m}$ cryostat sections were thaw-mounted onto gelatincoated slides. In order to remove endogenous glutamate, all sections underwent a prewash for 30 min at $2{ }^{\circ} \mathrm{C}$ in $50 \mathrm{mM}$ Tris- $\mathrm{HCl}$ buffer containing $2.5 \mathrm{mM} \mathrm{CaCl} 2, \mathrm{pH} \mathrm{7.20}$. Tissues were incubated for $45 \mathrm{~min}$ at $2^{\circ} \mathrm{C}$ with 20 concentrations (1 $n M-1 \mathrm{mM}$ ) of quisqualate in the presence of 200 $n M L-\left[{ }^{3} \mathrm{H}\right]$ glutamate.
After the incubation, sections were rinsed quickly with cold buffer, then cold $2.5 \%$ glutaraldehyde in acetone $(v / v)$, and blown dry with warm air. Dried sections were placed in cassettes with radioactive standards and apposed to LKB Ultrofilm ${ }^{3} \mathrm{H}$. The film was exposed to the tissue sections for 14 to 21 days at $4^{\circ} \mathrm{C}$. then developed, fixed and dried. All data presented were analyzed densitometrically from resultant autoradiographic images. Twenty-three sections incubated in 20 different concentrations of quisqualate were analyzed from each of 4 individual animals for each batch of quisqualate. Sixteen to 25 density readings were taken from the striatum of each tissue section. $K_{i}$ values were determined by the computer program LIGAND (Munson and Rodbard, 1980).

\section{Results}

\section{Contaminants detected by HPLC}

In our HPLC system, glutamate, aspartate, and quisqualate appear as separate resolvable peaks. The quisqualate peaks appear quite large, relative to the contaminant peaks, as it was necessary to use high concentrations of quisqualate in order to determine accurately the concentration of contaminants. NMDA was not detectable in our system, which employs derivatization of the free amino group of amino acids.

Six different batches of quisqualate from four separate sources were tested. Every batch tested had small contaminant peaks detectable by HPLC. These peaks were not present in control samples which omitted quisqualate. Batches differed in the number of these peaks and their sizes (Fig. 1). All quisqualate preparations also showed signs of contamination in thin layer chromatography (data not shown).

All batches of quisqualate tested were found to possess a peak which co-eluted with exogenously added glutamate (Fig. 2). In order to quantify the amount of this 'glutamate-like' contaminant, samples of quisqualate $(333 \mathrm{pmol})$ were chromatographed along with various concentrations $(0,1.67$, 3.33 , and $5 \mathrm{pmol}$ ) of glutamate in a sample volume of $10 \mu \mathrm{l}$. The percentage of glutamate-like contaminant ranged from 0.08 to $0.60 \%$. 

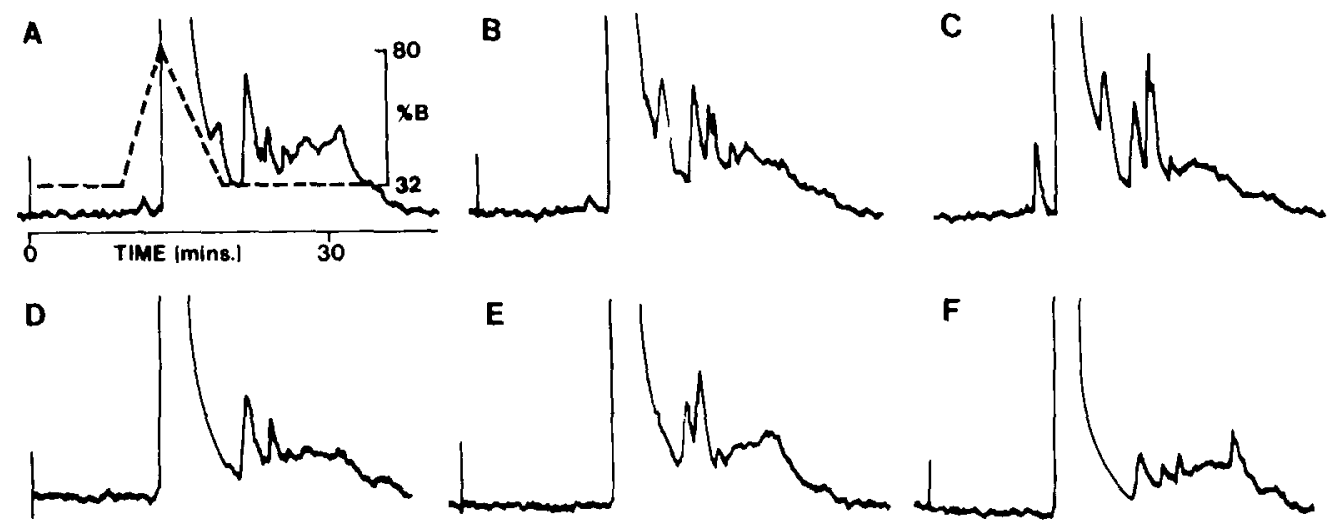

Fig. 1. High-pressure liquid chromatography records of 6 different quisqualate preparations. Dotted line represents percentage organic phase. Aqueous phase was $50 \mathrm{mM}$ sodium acetate. $\mathrm{pH} 5.0$. Organic phase was methanol : acetonitrile: tetrahydrofuran (5:4:1). Quisqualate preparations: A: Sigma 26F-0056; B: Sigma 106F-0622: C: Sigma 55F-0015: D: CRB A005/2177: E: RBI JC-487: F: synthetic (from J. Collins). All batches demonstrate contaminant peaks. The amount of contamination varies from batch to batch.

Three of the batches were found to possess a peak which co-eluted with exogenously added aspartate, and the amount of 'aspartate-like' contaminant was determined in the same fashion as for glutamate. The percentage of aspartate-like contaminant ranged from 0.34 to $0.85 \%$ (Table I). No aspartate-like contaminant was detected in synthetic quisqualate preparations, only in quisqualate preparations isolated from natural sources.

Behavior of different quisqualate preparations in a glutamate-binding assay

Quisqualate displaces $\mathrm{L}-\left[{ }^{3} \mathrm{H}\right]$ glutamate binding in a biphasic manner, with the 'high-affinity' com-

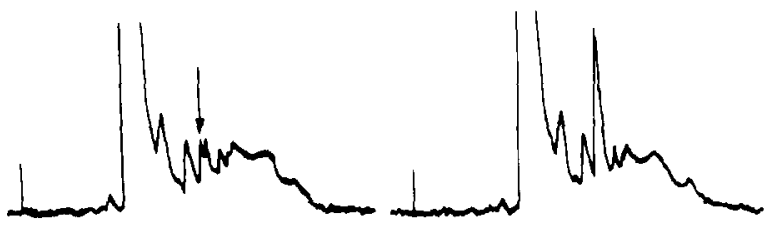

Fig. 2. Contaminant peak which behaves like glutamate. A: 333.3 pmol quisqualate (Sigma batch 106F-0622), demonstrating a large quisqualate peak with several smaller contaminant peaks. B: $333.3 \mathrm{pmol}$ quisqualate with $1.667 \mathrm{pmol}$ exoge nously added glutamate. The added glutamate co-elutes with one of the contaminant peaks, indicated with an arrow. Each preparation of quisqualate tested had a peak which co-eluted with exogenously added glutamate. In a similar fashion, some preparations of quisqualate had other contaminant peaks which co-eluted with exogenously added aspartate. ponent representing displacement of $\mathrm{L}$ $\left[{ }^{3} \mathrm{H}\right]$ glutamate from quisqualate receptors (Greenamyre et al., 1985; Olson et al., 1987; Cha et al., 1988). The portion of $\mathrm{L}-\left[{ }^{3} \mathrm{H}\right]$ glutamate binding which has low affinity for quisqualate likely represents glutamate binding to NMDA receptors (Greenamyre et al., 1985, 1987; Foster and Fagg. 1987; Cha et al., 1988). Thus the $K_{\mathrm{i}}$ value for the 'high-affinity' portion of the quisqualate displacement curve reflects the potency of a given batch of quisqualate at quisqualate receptors, whereas the $K_{\mathrm{i}}$ value for the 'low-affinity' portion represents interaction with 'non-quisqualate' (likely NMDA) receptors.

All six batches of quisqualate tested produced a biphasic displacement curve of $\mathrm{L}-\left[{ }^{3} \mathrm{H}\right]$ glutamate, as expected. High-affinity $K_{\mathrm{i}}$ values of the 6 quisqualate preparations were not significantly different from each other ( $P>0.05$, by one-way ANOVA), indicating that they all possessed similar potency at quisqualate receptors. In contrast, the low-affinity $K_{\mathrm{i}}$ values were significantly different from each other $(P<0.05$ by one way ANOVA, $F_{5,18}=3.467$ ), indicating that different batches had differing potencies at non-quisqualate receptors (Table I).

Although glutamate and aspartate are both agonists at NMDA receptors, they do not possess identical affinities. Thus, under the present assay 
TABLE I

LEVELS OF GLUTAMATE AND ASPARTATE CONTAMINATION, AND $K_{\mathrm{i}}$ VALUES IN 6 DIFFERENT PREPARATIONS OF QUISQUALATE

$K_{i}$ values represent mean \pm S.E.M. of 4 animals. There were no significant differences at the 'high-affinity' site, but batches had significantly different affinities at the 'low-affinity' site. GLU-like = glutamate-like contaminant, ASP-like = aspartate-like contaminant.

\begin{tabular}{|c|c|c|c|c|c|c|}
\hline \multicolumn{2}{|c|}{ Quisqualate preparation } & \multicolumn{3}{|c|}{ Contamination (\%) } & \multicolumn{2}{|l|}{$K_{\mathrm{i}}$ values } \\
\hline Supplier & Batch & GLU-like & ASP-like & $\mathrm{GLU}+(0.125) \mathrm{ASP}$ & 'High affinity' (nM) & 'Low affinity' $(\mu \mathrm{M})$ \\
\hline Sigma & $55 \mathrm{~F}-0015$ & 0.45 & 0.80 & 0.55 & $14.74 \pm 2.85$ & $26.97 \pm 6.96$ \\
\hline Sigma & $106 \mathrm{~F}-0622$ & 0.29 & 0.76 & 0.38 & $25.43 \pm 11.10$ & $74.40 \pm 17.10$ \\
\hline Sigma & $26 \mathrm{~F}-0056$ & 0.59 & 0.34 & 0.63 & $33.78 \pm 7.65$ & $110.5 \pm 36.9$ \\
\hline CRB & A005/2177 & 0.13 & $*$ & 0.13 & $10.36 \pm 6.20$ & $252.0 \pm 125.0$ \\
\hline RBI & JC- -487 & 0.25 & * & 0.25 & $86.37 \pm 42.44^{\dagger}$ & $256.0 \pm 30.0^{t}$ \\
\hline Dr. J. Collins & Synthetic & 0.08 & $*$ & 0.08 & $29.54 \pm 9.65$ & $227.6 \pm 53.7$ \\
\hline
\end{tabular}

* Not detectable, i.e. less than $200 \mathrm{fmol}$ of contaminant in 333.3 pmol of quisqualate sample. ${ }^{\dagger} n=3$ animals.

conditions, glutamate has a $K_{\mathrm{i}}$ value vs. NMDA binding which is eight times more potent than that of aspartate: $200 \mathrm{nM}$ for glutamate vs. $1.6 \mu \mathrm{M}$ for aspartate (Greenamyre et al., 1985). Aspartate-like contaminants would be expected to make a relatively weaker contribution than glutamate-like contaminants in displacing $\left[{ }^{3} \mathrm{H}\right]$ glutamate binding from non-quisqualate receptors. There was an excellent correlation between the percentage of glutamate-like contamination plus one-eighth of the percentage of aspartate-like contamination vs the low affinity $K_{\mathrm{i}}$ of a given batch of quisqualate $(r=0.86)$ (Fig. 3).

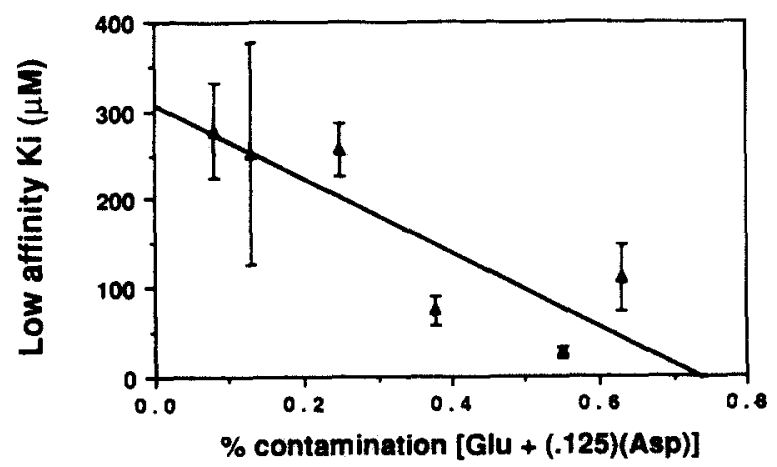

Fig. 3. Correlation of behavior of quisqualate preparations in a glutamate-binding assay with percentage contamination. The 'low-affinity' $K_{\mathrm{i}}$ values correlated very highly with (\% of glutamate-like contaminant $+(0.125)$ (\% aspartate-like contaminant)). Both glutamate and aspartate are known to interact with the NMDA receptor, but aspartate has one-eighth the affinity of glutamate. The Pearson correlation coefficient $r=$ 0.86 .

\section{Discussion}

In 1984, Olverman et al. reported the presence of glutamate in quisqualate as detected by high voltage paper electrophoresis. Wc report here detectable contamination using HPLC. Further, we report several HPLC-resolvable contaminant peaks in each batch of quisqualate tested. One of these contaminant peaks co-elutes with aspartate. This aspartate-like material was present only in quisqualate isolated from natural sources, whereas the glutamate-like contaminant appeared in all batches tested, whether the quisqualate had been synthesized or isolated from natural sources.

Different batches of quisqualate behaved differently in a bioassay: an autoradiographic $\left[{ }^{3} \mathrm{H}\right]$ glutamate-binding assay. Importantly, at low concentrations, at which the absolute levels of contaminants would be negligible, all batches of quisqualate possessed the same potency at quisqualate receptors. At higher concentrations of quisqualate, where the concentration of contaminants also rises, the quisqualate preparations differed from each other in their ability to interact with non-quisqualate receptors. The variable potency of quisqualate at non-quisqualate receptors suggests that it is the level of glutamate/ aspartate contamination, rather than an intrinsic action of quisqualate itself, which explains the apparent affinity of quisqualate for non-quisqualate receptors. The apparent potency of quisqua- 
late at NMDA receptors would be expected to vary if the effect were mediated by contaminants, since the concentration of contaminants would be likely to vary from batch to batch. The contaminant hypothesis is greatly strengthened by the finding that the potency of batches of quisqualate at non-quisqualate receptors correlates extremely well with the percentage of glutamate and aspartate contamination in these quisqualate preparations.

Certain commercially available quisqualate preparations (Sigma) are isolated from natural sources via a process which could leave residual aspartate and glutamate (see, e.g. Takemoto et al., 1975a). We have been able to detect contaminants which behave identically to aspartate and glutamate in these samples. Other quisqualate preparations (Cambridge Research Biochemicals, Research Biochemicals) are synthesized chemically. The best known schemes for quisqualate synthesis employ no glutamate in the process, and it is unlikely that any glutamate is formed as a side product (for examples, see Takemoto et al., 1975b; Bycroft et al., 1984). Thus, the appearance of glutamate-like contaminants in these batches was surprising. However, contaminant glutamate may derive from slightly contaminated starting materials and be carried throughout the synthetic procedure. It is relevant to note that we have employed a criterion for purity in the present study which exceeds that normally used in commercial preparative procedures. No aspartate-like contaminant was detected in any of the synthetic quisqualates, and in general, they possessed fewer contaminant peaks. Although purified natural quisqualate contains only the L-isomer, synthetic preparations might contain a racemic mixture of $\mathrm{D}$ - and $\mathrm{L}$-isomers of quisqualate. This could produce the generally higher $K_{\mathrm{i}}$ values for synthetic preparations at the low affinity site if one isomer were significantly less potent than the other. The fact that the synthetic preparation $K_{\mathrm{i}}$ values at the high-affinity site are not significantly different from those for quisqualate preparations isolated from natural sources argues against this explanation. It is more parsimonious to attribute the variability in low affinity $K_{\mathrm{i}}$ values to a variable incidence of detectable glutamate-like and aspartate-like contaminants.
We emphasize that the amount of contamination is small, with all batches tested being pure to greater than $98 \%$. However, at high concentrations of quisqualate, contaminants may achieve a relevant concentration and exert spurious effects. Because glutamate has a high affinity for excitatory amino acid receptors relative to other available ligands, the problem of contaminant aspartate and especially glutamate may become important in certain experimental paradigms. Further, we have not been able to identify all of the contaminant peaks which we observe. The possibility exists that these unknown substances themselves possess affinity for glutamate receptors, since they behave chromatographically similarly to known glutamate agonists (glutamate, aspartate, and quisqualate).

These findings have the potential to explain the unexpected effects of quisqualate at NMDA receptors. Foster and Fagg (1987) found that quisqualate at high concentrations could interact with NMDA receptor binding. Olverman et al. (1984) have proposed that glutamate contamination might explain the apparent affinity of quisqualate for NMDA receptors. The data presented here are consistent with this proposal. Several groups have reported that at the single ion channel level, quisqualate can infrequently produce channel openings characteristic of NMDA-type receptors (Christiansen and Nowak, 1987; Cull-Candy and Usowicz, 1987; Jahr and Stevens, 1987). If the quisqualate used was slightly contaminated with aspartate or glutamate, either of these compounds could effect openings of the NMDA-activated channel.

Finally, the possibility arises that quisqualate may be a much more selective ligand for the quisqualate receptor than had previously been supposed. The development of more pure preparations of quisqualate may permit a more precise pharmacological investigation of the glutamate receptor subclasses.

\section{Acknowledgements}

Supported by NIH NRSA 5T32 GM07863 and USPHS Grant NS 19613. 


\section{References}

Bycroft, B.W., Chhabra, S.R., Grout, R.J. and P.J. Crowley (1984) A convenient synthesis of the neuroexcitatory amino acid quisqualic acid and its analogues, J. Chem. Soc. Chem. Commun., 1156.

Cha, J.J., Hollingsworth, Z., Greenamyre, J.T., Collins, J., Penney, J.B. and A.B. Young (1987) Possible contamination of quisqualic acid by naturally occurring glutamic acid detected by quantitative autoradiography and HPLC analysis, Soc. Neurosci. Abstr., 13: 1564.

Cha, J.J., Greenamyre, J.T., Nielsen, E.Ø., Penney, J.B. and A.B. Young (1988) Properties of quisqualate-sensitive L$\left[{ }^{3} \mathrm{H}\right]$ glutamate binding sites in rat brain as determined by quantitative autoradiography, J. Neurochem., 51: 463-478.

Christiansen, J.L. and L.M. Nowak (1987) AMPA-activated channels in mammalian cerebellar neurons, Soc. Neurosci. Abstr., 13: 753.

Cull-Candy, S.G. and M.M. Usowicz (1987) Multiple-conductance channels activated by excitatory amino acids in cerebellar neurons, Nature (Lond.), 325: 525-528.

Fernstrom, M.H. and J.D. Fernstrom (1981) Rapid measurement of free amino acids in serum and CSF using high-performance liquid chromatography, Life Sci., 29: 2119-2130.

Foster, A.C. and G.E. Fagg (1987) Comparison of L$\left[{ }^{3} \mathrm{H}\right]$ glutamate, D- $\left[{ }^{3} \mathrm{H}\right]$ aspartate, DL- $\left[{ }^{3} \mathrm{H}\right] \mathrm{APS}$ and $\left[{ }^{3} \mathrm{H}\right]$ NMDA as ligands for NMDA receptors in crude postsynaptic densities from rat brain, Eur. J. Pharmacol., 133: 291-300.

Greenamyre, J.T., Young, A.B., and J.B. Penney (1984) Quantitative autoradiographic distribution of L.- $\left[{ }^{3} \mathrm{H}\right]$ glutamate-binding sites in rat central nervous system. J. Neurosci., 4: 2133-2144.

Greenamyre, J.T., Olson, J.M.M., Penney, J.B. and A.B. Young (1985) Autoradiographic characterization of N-methyl-Daspartate-, quisqualate- and kainate-sensitive glutamate binding sites, J. Pharm. Exp. Ther., 233: 254 263.

Greenamyre, J.T., Penney, J.B., Young, A.B., Hudson. C. Silverstein, F.S. and M.V. Johnston (1987) Evidence for transient perinatal glutamatergic innervation of globus pallidus, J. Neurosci., 7: 1022-1030.

Jahr, C.E. and Stevens, C.F. (1987) Glutamate activates multiple single channel conductances in hippocampal neurons, Nature (Lond.), 325: 522-525.

Munson, P.J. and Rodbard, D. (1980) Ligand: a versatile computerized approach for the characterization of ligandbinding systems, Analyt. Biochem., 107: 220-239.

Olson, J.M.M., Greenamyre, J.T., Penney, J.B. and A.B. Young (1987) Autoradiographic localization of cerebellar excitatory amino acid binding sites in the mouse, Neuroscience. 22: 913-923.

Olverman, H.J., Jones, A.W. and J.C. Watkins (1984) LGlutamate has a higher affinity than other amino acids for $\left[{ }^{3} \mathrm{H}\right]-\mathrm{D}$-AP5 binding sites in rat brain membranes, Nature (Lond.), 307: 460-462.

Takemoto, T., Takagi, N., Nakajima, T. and K. Koike (1975a) Studies on the constituents of Quisqualic fructus. I. On the amino acids, Yakugaku Zasshi, 95: 176-179.

Takemoto, T., Koike, K., Makajima, T. and S. Arihara (1975b) Studies on the constituents of Quisqualic fructus. III. Synthesis of quisqualic acid and related compounds. Yakugaku Zasshi, 95: 448-452.

Watkins, J.C. and R.H. Evans (1981) Excitatory amino acid transmitters, Annu. Rev. Pharmacol. Toxicol.. 21: 165-204. 